\title{
IMMUNOCHEMICAL INVESTIGATIONS ON LIPOPOLYSAC- CHARIDES AND ACIDIC POLYSACCHARIDES FROM SERUM-SENSITIVE AND SERUM-RESISTANT STRAINS OF ESCHERICHIA COLI ISOLATED FROM URINARY- TRACT INFECTIONS
}

\author{
P. W. TAYLOR \\ Department of Medicine, Charing Cross Hospital Medical School, \\ Fulham Palace Road, London W6 8RF
}

I $\mathrm{T}$ is well established that normal human serum possesses bactericidal activity against a wide range of gram-negative bacteria. Although some aspects of killing by serum are not well understood, bactericidal antibody and at least some of the components of complement are known to interact with structures in the outer membrane of the bacterial cell (Inoue, 1972). The killing of both smooth and rough strains usually requires antibody directed against the polysaccharide side chain $(\mathrm{O})$ or core $(\mathrm{R})$ antigenic determinants of lipoplysaccharide (LPS; Muschel, 1960; Chedid et al., 1968); activated complement components appear to be fixed by the lipid A moiety of LPS (Mergenhagen et al., 1968; Galanos et al., 1971; for a review of LPS structure see Lüderitz et al., 1971).

The LPS in serum-sensitive strains is assumed to be freely available to interact with antibody and complement. Studies of resistance to serum have therefore been concerned with cell-surface structures that might impede the attachment or subsequent activity of the serum factors. Mutations leading to reduction or loss of O side-chains of LPS result in a marked increase in serum sensitivity (Nelson and Roantree, 1967; Dlabač, 1968; Muschel and Larsen, 1970); it has therefore been suggested that long or numerous $O$ side-chains interfere with the functioning of complement and are thus responsible for resistance to serum. Furthermore, phenotypic modification from serum resistance to serum sensitivity is accompanied by a striking reduction in the ratio of $O$ side-chain to core sugars (Feingold, 1969). In these studies the structural changes were extensive since the serum-sensitive cells showed rough characteristics. Many naturally occurring serum-sensitive strains are completely smooth by cultural, morphological and serological criteria and are indistinguishable in these respects from serum-resistant organisms.

Because larger amounts of LPS can be extracted from smooth serum-resistant strains than from rough serum-sensitive strains, some workers have suggested that serum resistance is due to large amounts of LPS in the envelope (Wardlaw, 1963; Reynolds and Pruul, 1971).

It was established by Muschel (1960) that the serum resistance of Escherichia coli is partially correlated with inagglutinability in O antisera. Glynn and Howard (1970) investigated the possibility that polymers known to play a role in $\mathrm{O}$ inagglutinability might also be responsible for the resistance of $E$. coli to antibody and complement. They found that crude homogenates of serum-resistant strains were in general more able to inhibit non-specifically

Received 20 Nov. 1975; revised version accepted 16 Feb. 1976.

J. MED. MICROBIOL.-VOL. 9 (1976) 
TABLE I

Smooth strains of Escherichia coli used in this study

\begin{tabular}{|c|c|c|c|}
\hline \multirow{2}{*}{ Serotype } & \multicolumn{3}{|c|}{$\begin{array}{l}\text { Serial numbers of strains giving the indicated } \\
\text { response to serum }\end{array}$} \\
\hline & $\begin{array}{c}\text { Sensitive } \\
\text { (Grades } 1,2)\end{array}$ & $\begin{array}{l}\text { Intermediate } \\
\text { (Grades 3, 4) }\end{array}$ & $\begin{array}{c}\text { Resistant } \\
\text { (Grades 5, 6) }\end{array}$ \\
\hline $\mathrm{O} 2$ & $\begin{array}{l}\text { LP1173 (a)* } \\
\text { LP2362 (b) }\end{array}$ & $\begin{array}{l}\text { LP1624 (a) } \\
\ldots\end{array}$ & $\begin{array}{l}\mathrm{LP} 2017 \text { (b) } \\
\ldots\end{array}$ \\
\hline O6 & $\begin{array}{l}\text { LP944 (c) } \\
\text { LP1894 (d) } \\
\text { LP2707 (e) } \\
\text { LP856a (f) } \\
\ldots . .\end{array}$ & $\begin{array}{l}\text { LP898 } \\
\text { LP1174 } \\
\text { LP1339 } \\
\text { LP2155 } \\
\text { LP2671 }\end{array}$ & $\begin{array}{c}\text { LP1107 (c) } \\
\text { LP1123 (f) } \\
\text { LP2214 (d) } \\
\text { LP2706 (e) } \\
\ldots\end{array}$ \\
\hline 07 & $\begin{array}{l}\text { LP903 } \\
\text { LP1674 (g) }\end{array}$ & $\cdots$ & $\begin{array}{l}\mathrm{LP} 1170(\mathrm{~g}) \\
\ldots\end{array}$ \\
\hline O9 & $\begin{array}{l}\text { LP609 } \\
\text { LP729 } \\
\text { LP1977 (h) }\end{array}$ & $\begin{array}{l}\ldots \\
\cdots \\
\cdots\end{array}$ & $\begin{array}{c}\mathrm{LP} 1255(\mathrm{~h}) \\
\ldots \\
\ldots\end{array}$ \\
\hline 018 & $\begin{array}{l}\text { LP2212 (i) } \\
\text { LP2506 (j) }\end{array}$ & $\begin{array}{l}\cdots \\
\cdots\end{array}$ & $\begin{array}{l}\text { LP1301 (i) } \\
\text { LP1395 (j) }\end{array}$ \\
\hline
\end{tabular}

* Pairing of strains for statistical analysis is indicated by the letters in parentheses.

the agglutination of red cells by anti-red-cell serum than homogenates of serum-sensitive strains. This inhibition was interpreted as being due to $\mathbf{K}$ antigens in the preparations. Moreover, purified $\mathrm{K}$ antigen from a serum-resistant strain had greater inhibitory activity than equal amounts of $\mathrm{K}$ antigen from a serum-sensitive strain.

A series of immunochemical and genetic investigations were recently undertaken in this laboratory in an attempt to define the basis of serum resistance of $E$. coli. In this study urinary strains of similar $O$ serotype but differing in serum sensitivity were examined to determine whether current theories could explain the behaviour of these strains in normal human serum.

\section{MATERIALS AND METHODS}

Strains. Twenty-eight culturally smooth strains of $E$. coli, isolated from confirmed cases of urinary-tract infection and belonging to serogroups $\mathrm{O} 2, \mathrm{O} 6,07,09$, and $\mathrm{O} 18$, were selected for investigation. The sensitivity of the strains to normal human serum as determined by the technique of Taylor, Roberts and Gower (1972) is shown in table I. The results are categorised into six grades, grade 1 being the most serum sensitive and grade 6 the most serum resistant. For convenience and comparison, strains in grades 1 and 2 were considered to be serum sensitive and strains in grades 5 and 6 to be serum resistant; grades 3 and 4 were taken as intermediate (Taylor, 1974).

E. coli strains F470, F576 and F653, obtained from Dr G. Schmidt, Max-Planck-Institut für Immunbiologie, Freiburg, Germany, are rough strains with complete $E$. coli R1, R2 and R3 LPS cores respectively (Schmidt, Jann and Jann 1969; Schmidt, Fromme and Mayer, 1970). 
Sensitivity to bacteriophages. Acidic polysaccharides and LPS O side-chains are known to interfere with the attachment of rough-specific phages. The phage sensitivity of the bacterial strains was therefore determined with six phages (nos. F0, Br2, Br10, Fp1, 6SR and C21) which are actively lytic against certain $\mathrm{R}$ forms of $E$. coli (Schmidt et al., 1969). Phages were propagated on suitable host strains and bacterial sensitivity was determined by applying drops of phage containing approximately $10^{8}$ p.f.u. per $\mathrm{ml}$ on to surface-inoculated nutrientagar plates. The phages and their host strains were supplied by Dr G. Schmidt.

Preparation of LPS and acidic polysaccharides. The bacteria were grown in $4 \times 700-\mathrm{ml}$ amounts of Nutrient Broth (Oxoid no. 2) in 2.5-litre conical flasks. The cultures were incubated in an orbital incubator $\left(120\right.$ orbits per min.) at $37^{\circ} \mathrm{C}$ for $16 \mathrm{~h}$, harvested by centrifugation $\left(0^{\circ} \mathrm{C}\right)$, washed twice with $0.4 \% \mathrm{NaCl}$ and dried to constant weight over $\mathrm{P}_{2} \mathrm{O}_{5}$.

Two batches of each strain were prepared. One was extracted with $45 \%$ phenol at $68^{\circ} \mathrm{C}$ (Westphal and Jann, 1965) and the other with $0.9 \% \mathrm{NaCl}$ at $60^{\circ} \mathrm{C}$ as described by Jann et al. (1970). Extracts obtained by both methods were subjected to fractional cetrimide precipitation according to procedure III of Westphal and Jann (1965). Fractions representing acidic polysaccharides and LPS were freeze dried and weighed. The yield was expressed as the weight of antigen $(\mathrm{mg})$ per $\mathrm{g}$ dry weight of bacterial cells. Phenol-soluble LPS has been found by Hickman and Ashwell (1966) and by Raff and Wheat (1968). Therefore, all phenol layers from phenol-water extractions were examined for LPS.

Hydrolysis of LPS. Optimal conditions for release of neutral sugars were determined by subjecting LPS from an E. coli $\mathrm{O} 7$ strain (no. LP903) to hydrolysis in $0.1 \mathrm{~N} \mathrm{HCl}, 0.5 \mathrm{~N} \mathrm{H}_{2} \mathrm{SO}_{4}$, and $1 \mathrm{~N} \mathrm{H}_{2} \mathrm{SO}_{4}$ for varying periods at $100^{\circ} \mathrm{C}$. The highest values were obtained after hydrolysis for $48 \mathrm{~h}$ in $\mathrm{O} \cdot 1 \mathrm{~N} \mathrm{HCl}$; lower values for L-glycero-D-mannoheptose and rhamnose were found when other hydrolysis conditions were applied. The same optimum was established by Schmidt et al. (1970) for the release of neutral sugars from Salmonella greenside R LPS.

Determination of neutral sugars of LPS. LPS $(2 \mathrm{mg})$ was hydrolysed $\left(100^{\circ} \mathrm{C}, 48 \mathrm{~h}\right)$ in sealed tubes containing $0.1 \mathrm{~N} \mathrm{HCl}(2 \mathrm{ml}) ; 0.1 \mathrm{ml}$ of $0.005 \mathrm{M}$ xylose was then added as an internal standard (Schmidt et al., 1970) and the hydrolysate neutralised with Amberlite IRA $410\left(\mathrm{HCO}_{3}{ }^{-}\right)$. The neutral solution was treated with E. coli alkaline phosphatase (Sigma Chemical Co. Ltd, St Louis, Mo, USA) to remove heptose-linked phosphate residues (Hämmerling et al., 1971) and then reduced with sodium borohydride $(5 \mathrm{mg})$ overnight at room temperature. Excess borohydride was destroyed with Dowex $50 \mathrm{~W}-\mathrm{X} 8\left(\mathrm{H}^{+}\right)$, the hydrolysate dried and boric acid removed by three reduced-pressure distillations with methanol (Holme et al., 1968). The syrups were dried and then heated at $100^{\circ} \mathrm{C}$ for $10 \mathrm{~min}$. in $1 \mathrm{ml}$ of acetic anhydride + pyridine $(1: 1)$; excess acetic anhydride was destroyed by adding water and the solutions were dried over $\mathrm{P}_{2} \mathrm{O}_{5}$. The resulting alditol acetates were dissolved in $0.2 \mathrm{ml}$ of chloroform and analysed by gas-liquid chromatography (Sawardeker, Sloneker and Jeanes, 1965). Samples ( $1 \mu$ litre) were injected into a Pye Unicam Series 104 chromatograph fitted with $2.7 \mathrm{~m} \times 0.6 \mathrm{~cm}$ glass columns containing $3 \%$ ECNSS-M on 100/120 mesh Gas-Chrom $Q$ (Applied Science Laboratories Inc., State College, Penn., USA). Separations were obtained isothermally at $180^{\circ} \mathrm{C}$ by the use of a nitrogen-carrier gas-flow rate of $45 \mathrm{ml}$ per min.; the injection port temperature was $250^{\circ} \mathrm{C}$. Peaks were identified by comparison with authentic alditol acetates prepared from the corresponding acid-treated $\left(0 \cdot 1 \mathrm{~N} \mathrm{HCl}, 48 \mathrm{~h}, 100^{\circ} \mathrm{C}\right)$ neutral sugars.

Pentoses, methylpentoses and hexoses were obtained from BDH Chemicals Ltd, Poole, Dorset; persitol, the reduction product of L-glycero-D-mannoheptose, was provided by Dr E. Zissis, National Institutes of Health, Bethesda, Md., USA. D-glycero-D-mannoheptose was a gift from Dr M. Perry, National Research Council of Canada, Ottawa. Under the chromatographic conditions used, alditol acetates of all neutral sugars known to be present in the $E$. coli LPS considered in this study were readily separated.

Other estimations. Hexosamine was determined according to Strominger, Park and Thompson (1959) with glucosamine as standard; lipid A was removed after hydrolysis in $1 \%$ acetic acid at $100^{\circ} \mathrm{C}$ for $90 \mathrm{~min}$.

3-deoxy-D-manno-octulosonic acid (KDO) was estimated by a modification of the thio- 
barbiturate method described by Ellwood (1970); synthetic KDO ammonium salt, prepared by the condensation of D-arabinose and oxalacetic acid (Ghalambor, Levine and Heath, 1966), was used as standard.

Hexuronic acids were determined according to Dische (1947); neuraminic acid was estimated with the modified Ehrlich procedure (Barry, Abbott, and Tsai, 1962). The method of Lowry et al., (1951) was used for protein estimation.

Chromatography of degraded polysaccharides. The method of Müller-Seitz, Jann and Jann (1968) was followed. LPS (50 mg) from one strain (no. LP729) was degraded in 1\% acetic acid at $100^{\circ} \mathrm{C}$ for $90 \mathrm{~min}$. After removal of lipid A, degraded polysaccharides were fractionated on Sephadex G50 (Pharmacia AB, Uppsala, Sweden) with pyridine acetate as eluant (Schmidt et al., 1969). The sugar content of 6-ml fractions was determined by the phenol- $\mathrm{H}_{2} \mathrm{SO}_{4}$ technique (Dubois et al., 1956).

Passive haemagglutination (HA). $\mathrm{O}$ side-chains are known to interfere with the attachment of anti-R antibodies to the LPS core in HA and haemagglutination-inhibition tests (Schmidt et al., 1969, 1970). LPS from serum-sensitive and serum-resistant strains were therefore examined for differences in $\mathrm{O}$ side-chain content which might be correlated with serum-sensitivity.

$E$. coli $\mathrm{R}$ antisera were prepared in rabbits according to Schlecht and Westphal (1967). LPS $\left(1 \mathrm{mg}\right.$ ) was treated with $0.02 \mathrm{~N} \mathrm{NaOH}$ for $18 \mathrm{~h}$ at $37^{\circ} \mathrm{C}$ and, after neutralisation, was added to $6 \mathrm{ml}$ of $0.5 \%$ sheep RBC. After incubation for $1 \mathrm{~h}$ at $37^{\circ} \mathrm{C}$ the cells were washed and resuspended in $0.9 \% \mathrm{NaCl}$. Serial two-fold dilutions of antiserum $(0.1 \mathrm{ml})$ were made in WHO trays with $0.9 \% \mathrm{NaCl}$ as diluent and $0.1 \mathrm{ml}$ of sensitised sheep RBC were added. The trays were incubated at $37^{\circ} \mathrm{C}$ for $1 \mathrm{~h}$ and haemagglutination titres (highest dilution showing complete agglutination) recorded after $1 \mathrm{~h}$ at room temperature.

Haemagglutination inhibition (HAI). Serial two-fold dilutions $(0 \cdot 1 \mathrm{ml})$ of LPS ( $250 \mu \mathrm{g}$ per $\mathrm{ml}$ ) were made in WHO trays. R antiserum (4 haemagglutination units; $0.1 \mathrm{ml}$ ) was added to each well and the trays were incubated for $1 \mathrm{~h}$ at $37^{\circ} \mathrm{C} ; 0 \cdot 2-\mathrm{ml}$ amounts of sensitised sheep $\mathrm{RBC}(0.5 \%)$ were then added. After incubation at $37^{\circ} \mathrm{C}$ for $1 \mathrm{~h}$ the lowest inhibitor concentration causing total inhibition of haemagglutination was recorded.

Inhibition of red-cell agglutination (Glynn and Howard, 1970). Serial two-fold dilutions $(0.5 \mathrm{ml})$ of acidic polysaccharide $(1 \mathrm{mg}$ per $\mathrm{ml})$ were made in phosphate-buffered saline (PBS). Equal amounts of $1 \%$ sheep RBC in PBS were then added. After incubation at $37^{\circ} \mathrm{C}$ for $30 \mathrm{~min}$., the cells were washed three times in PBS. Serial two-fold dilutions $(0 \cdot 1 \mathrm{ml})$ of rabbit anti-sheep red-cell serum (Wellcome Reagents Ltd, Beckenham, Kent) were prepared in the horizontal rows of a WHO tray with PBS as diluent. The sheep RBC sensitised with various amounts of inhibitor substance were then added in vertical rows, thus forming a chequerboard titration. The plates were incubated at $37^{\circ} \mathrm{C}$ for $1 \mathrm{~h}$ and then kept at $4^{\circ} \mathrm{C}$ overnight. The HAI activity was expressed as the amount of inhibitor necessary to double the minimal agglutinating dose of the anti-red-cell serum.

Statistical analyses. When results from all serum-resistant and serum-sensitive strains were compared, regardless of $O$ specificity, the significance of the difference of the means was assessed by means of Student's $t$ test.

As serum sensitivity may be related to the O serotype (Taylor, 1974), in some cases comparisons were made between randomly-paired strains of the same $O$ serotype. The pairing is indicated in table 1 by the letters in parentheses following the strain number. In these cases the significance of the mean difference was assessed using Student's $t$ test except for the comparison of titres, when the Wilcoxon signed rank (T) test was used (Wilcoxon, 1945).

\section{RESULTS}

\section{Bacteriophage sensitivity of the $E$. coli strains}

The phages designated F0, Br2, Br10, Fp1, 6SR and C21 interact with receptors in the core of the bacterial LPS; absorption of these phages may 
TABLE II

Phage-sensitivity patterns of smooth and rough strains of E. coli

\begin{tabular}{|c|c|c|c|c|c|c|c|}
\hline \multirow{2}{*}{ Strain no. } & \multirow{2}{*}{ Serotype } & \multicolumn{6}{|c|}{ Reaction obtained* with R-specific phage no. } \\
\hline & & FO & $\mathrm{Br} 2$ & Br10 & Fp1 & $6 \mathrm{SR}$ & $\mathrm{C} 21$ \\
\hline $\begin{array}{l}\text { LP2362 } \\
\text { LP1894 } \\
\text { LP609 } \\
\text { LP729 }\end{array}$ & $\begin{array}{c}\mathrm{O} 2: \mathrm{K} ?: \mathrm{H} 6 \\
\mathrm{O} 6: \mathrm{K} ?: \mathrm{H} 1 \\
\text { O9 } \\
\text { O9 }\end{array}$ & $\begin{array}{l}- \\
\overline{(+)}\end{array}$ & $\begin{array}{l}- \\
\overline{-} \\
-\end{array}$ & $\begin{array}{l}- \\
\overline{-} \\
-\end{array}$ & $\begin{array}{l}+ \\
(+) \\
+ \\
+\end{array}$ & $\begin{array}{l}- \\
- \\
-\end{array}$ & $\begin{array}{l}- \\
\pm \\
+\end{array}$ \\
\hline $\begin{array}{l}\text { F470 } \\
\text { F576 } \\
\text { F653 }\end{array}$ & $\begin{array}{l}\mathrm{R} 1 \\
\mathrm{R} 2 \\
\mathrm{R} 3\end{array}$ & \pm & $\begin{array}{l}- \\
+ \\
+\end{array}$ & $\begin{array}{l}+ \\
+ \\
+\end{array}$ & $\begin{array}{l}+ \\
+ \\
+\end{array}$ & $\begin{array}{l}+ \\
+ \\
+\end{array}$ & $\begin{array}{l}+ \\
-\end{array}$ \\
\hline
\end{tabular}

be blocked by the presence of $\mathrm{O}$ side-chains or acidic polysaccharide (Rapin and Kalckar, 1971).

The 15 serum-resistant or serum-intermediate strains were resistant to all six phages, and although four of the 13 serum-sensitive strains were sensitive to at least one phage (table II) there was no clear relationship between serum sensitivity and sensitivity to these R-specific phages.

Strains LP2362 and LP1894 were sensitive to phage Fp1, which has its receptor deep in the LPS core (Rapin and Kalckar. 1971). Strain LP609 was lysed by phages $\mathrm{Fp} 1$ and $\mathrm{C} 21$, indicating that this strain probably possesses a R1 core; strain LP729 was sensitive to phage F0 and is thus likely to have a $\mathrm{R} 2$ core. No smooth strains were sensitive to phages $6 \mathrm{SR}$ and $\mathrm{Br} 2$; it has been found that even very small amounts of $O$ side chain material render strains resistant to these phages (Rapin and Kalckar, 1971).

\section{Effect of growth conditions on the serum sensitivity of the E. coli strains}

The response to serum of the strains selected for this study was determined on small batch cultures in the early log phase of growth. For the preparation of antigens, bacteria were cultivated in relatively large volumes and harvested just before the stationary phase. Cells harvested at different times during the growth cycle may vary in their sensitivity to serum (Rowley and Wardlaw, 1958), so the response to serum of the strains at the time of harvesting was estimated. After the cells were washed in $0.4 \% \mathrm{NaCl}$, a standardised inoculum in Tris- $\mathrm{HCl}, p \mathrm{H} 8.4$, was added to serum and sensitivity determined in the usual way (Taylor et al., 1972). Most of the results obtained with this modified bactericidal test agreed with those obtained with the standard bactericidal test. All three $E$. coli $\mathrm{O} 7$ strains, however, showed a marked change in response to serum. The two strains previously classed as sensitive were fully resistant, whereas the one resistant strain was clearly susceptible. Slightly modified 
responses to serum were also observed with three of the intermediate 06 strains.

\section{Studies on the lipopolysaccharide (LPS)}

Yield. There was no significant difference in the mean yield of LPS from serum-sensitive and serum-resistant strains (table III) as determined by either the standard test or the modified test, whether extracted by phenol-water (means $54.30-59.05 \mathrm{mg}$ per $\mathrm{g} ; t<0.800 ; \mathrm{P}>0.4$ ) or by saline (means 46.55 $50.59 \mathrm{mg}$ per $\mathrm{g} ; t<0.740 ; \mathrm{P}>0.4)$. Small amounts of LPS were extracted from strain LP1624. No phenol-soluble LPS was isolated from any of the strains.

Passive haemagglutination. LPS preparations from the $E$. coli strains were examined by $\mathrm{HA}$ with $\mathrm{R}$ antisera prepared against the $E$. coli $\mathrm{R} 1, \mathrm{R} 2$ and R3 reference strains. These tests, in addition to assessing the extent to which $O$ side-chains interfere with the attachment of antibodies to the LPS core, identify the LPS core type.

Titres of 5120 were obtained against the homologous R LPS with all three antisera. As previously noted by Schmidt et al. (1969, 1970), R2 and R3 LPS cross-react. LPS from 26 smooth strains reacted strongly with anti-R1 serum and are likely to have R1 cores; LPS from the remaining two strains, LP729 and LP1977, reacted with anti-R2 serum and therefore probably possess the R2 core-structure. No preparations reacted to any extent in anti-R3 serum. Some slight reactivity of S LPS in heterologous R antisera was found. Only three preparations reacted to the full titre of the appropriate anti-R serum; these were all from serum-sensitive strains. The lowest titre, 320, was found with LPS from three serum-resistant strains. However, 41 of the 56 preparations gave titres of 1280 or 2560 . There appears, therefore, to be little difference in the extent to which LPS from serum-sensitive, -intermediate and -resistant strains react with anti-R sera in passive haemagglutination tests.

Haemagglutination inhibition. The ability of LPS from the $E$. coli strains to inhibit the R1, R2 and R3 haemagglutination systems was determined. The R1, R2 and R3 systems were completely inhibited by the lowest doses of homologous R LPS used $(0.5 \mu \mathrm{g}$ per ml). LPS from strain F576 inhibited the $R 1$ and $R 2$ systems, although it did not react with anti-R1 serum in HA tests; this is because for HA, LPS is pre-treated with alkali whereas it is not when used as an inhibitor of HA. Thus, the groups that render F576 LPS reactive in anti-R1 sera are removed by alkali treatment (Schmidt et al., 1969).

The identification of the LPS core types by HA was confirmed by HAI. LPS with the R2 core did not inhibit the R1 haemagglutination system. LPS preparations varied markedly in their ability to inhibit the various $R$ systems. Preparations from two strains, LP1173 and LP2362, were as effective as the homologous R LPS and there was a tendency for LPS from serum-sensitive strains to be more effective inhibitors than those from serum-resistant strains; the difference, however, was not statistically significant (phenol-water extracts: $\mathrm{T}=16 ; \mathrm{P}>0.05 ;$ saline extracts: $\mathrm{T}=14 ; \mathrm{P}>0.05)$. 
TABLE III

Chemical analysis of lipopolysaccharides (LPS) extracted with phenol-water (PW) and warm saline (Sal) from E. coli strains

\begin{tabular}{|c|c|c|c|c|c|c|c|c|c|c|}
\hline \multirow[b]{2}{*}{$\begin{array}{c}\text { Strain } \\
\text { no. }\end{array}$} & \multirow[b]{2}{*}{ Extract } & \multirow[b]{2}{*}{$\begin{array}{l}\text { Yield: } \\
\text { mg per } \mathrm{g} \text { of } \\
\text { cell mass }\end{array}$} & \multicolumn{7}{|c|}{ Molar ratio of the product } & \multirow[b]{2}{*}{$\begin{array}{c}\text { Percentage } \\
\text { of hexosamine }\end{array}$} \\
\hline & & & Rhamnose & Mannose & Galactose & Glucose & $\begin{array}{c}\text { D-glycero- } \\
\text { D-manno- } \\
\text { heptose }\end{array}$ & $\begin{array}{c}\text { L-glycero- } \\
\text { D-manno- } \\
\text { heptose }\end{array}$ & $\mathrm{KDO}^{*}$ & \\
\hline LP1173 & \multirow{50}{*}{$\begin{array}{l}\text { PW } \\
\text { Sal } \\
\text { PW } \\
\text { Sal } \\
\text { PW } \\
\text { Sal } \\
\text { PW } \\
\text { Sal } \\
\text { PW } \\
\text { Sal } \\
\text { PW } \\
\text { Sal } \\
\text { PW } \\
\text { Sal } \\
\text { PW } \\
\text { Sal } \\
\text { PW } \\
\text { Sal } \\
\text { PW } \\
\text { Sal } \\
\text { PW } \\
\text { Sal } \\
\text { PW } \\
\text { Sal } \\
\text { PW } \\
\text { Sal } \\
\text { PW } \\
\text { Sal } \\
\text { PW } \\
\text { Sal } \\
\text { PW } \\
\text { Sal } \\
\text { PW } \\
\text { Sal } \\
\text { PW } \\
\text { Sal } \\
\text { PW } \\
\text { Sal } \\
\text { PW } \\
\text { Sal } \\
\text { PW } \\
\text { Sal } \\
\text { PW } \\
\text { Sal } \\
\text { PW } \\
\text { Sal } \\
\text { PW } \\
\text { Sal } \\
\text { PW } \\
\text { Sal } \\
\text { PW } \\
\text { Sal } \\
\text { PW } \\
\text { Sal } \\
\text { PW } \\
\text { Sal }\end{array}$} & \multirow{50}{*}{$\begin{array}{l}66 \cdot 3 \\
35 \cdot 5 \\
35 \cdot 6 \\
35 \cdot 5 \\
14 \cdot 0 \\
17 \cdot 0 \\
57 \cdot 9 \\
44 \cdot 2 \\
58 \cdot 3 \\
42 \cdot 8 \\
66 \cdot 6 \\
79 \cdot 0 \\
71 \cdot 7 \\
27 \cdot 6 \\
65 \cdot 5 \\
62 \cdot 0 \\
62 \cdot 6 \\
64 \cdot 7 \\
71 \cdot 8 \\
58 \cdot 1 \\
69 \cdot 3 \\
54 \cdot 5 \\
59 \cdot 6 \\
43 \cdot 7 \\
73 \cdot 5 \\
66 \cdot 6 \\
52 \cdot 4 \\
39 \cdot 3 \\
41 \cdot 1 \\
43 \cdot 8 \\
45 \cdot 2 \\
45 \cdot 4 \\
60 \cdot 9 \\
35 \cdot 0 \\
44 \cdot 8 \\
44 \cdot 4 \\
42 \cdot 4 \\
36 \cdot 2 \\
64 \cdot 5 \\
39 \cdot 0 \\
74 \cdot 5 \\
35 \cdot 7 \\
64 \cdot 6 \\
54 \cdot 6 \\
57 \cdot 4 \\
51 \cdot 7 \\
60 \cdot 6 \\
64 \cdot 1 \\
59 \cdot 7 \\
53 \cdot 5 \\
39 \cdot 4 \\
46 \cdot 6 \\
63 \cdot 4 \\
58 \cdot 5 \\
50 \cdot 9 \\
62 \cdot 1\end{array}$} & \multirow{11}{*}{$\begin{array}{l}2 \cdot 27 \\
1 \cdot 53 \\
0 \cdot 28 \\
0 \cdot 29 \\
1 \cdot 49 \\
4 \cdot 73 \\
2 \cdot 11 \\
5 \cdot 66 \\
0 \\
0 \\
0 \\
0\end{array}$} & \multirow{11}{*}{$\begin{array}{l}0 \\
0 \\
0 \\
0 \\
0 \\
0 \\
0 \\
0 \\
3 \cdot 70 \\
3 \cdot 03 \\
1 \cdot 87 \\
2 \cdot 66\end{array}$} & \multirow{11}{*}{$\begin{array}{l}3.12 \\
3.36 \\
1.56 \\
2.37 \\
2.97 \\
2.31 \\
1.24 \\
2.75 \\
1.68 \\
1.37 \\
1.64 \\
1.74\end{array}$} & \multirow{2}{*}{$\begin{array}{l}6 \cdot 12 \\
5 \cdot 22\end{array}$} & \multirow{2}{*}{$\begin{array}{l}0 \\
0\end{array}$} & \multirow{2}{*}{$\begin{array}{l}1 \cdot 00 \\
1 \cdot 00\end{array}$} & \multirow{2}{*}{$\begin{array}{l}2.40 \\
1.46\end{array}$} & $9 \cdot 2$ \\
\hline & & & & & & & & & & $5 \cdot 2$ \\
\hline LP2362 & & & & & & 1.66 & 0 & 1.00 & $1 \cdot 18$ & $3 \cdot 0$ \\
\hline & & & & & & 3.00 & 0 & 1.00 & $1 \cdot 47$ & $0 \cdot 7$ \\
\hline LP1624 & & & & & & $5 \cdot 27$ & 0 & 1.00 & $2 \cdot 46$ & $10 \cdot 3$ \\
\hline \multirow{2}{*}{ LP2017 } & & & & & & $1 \cdot 14$ & 0 & 1.00 & $1 \cdot 32$ & $9 \cdot 2$ \\
\hline & & & & & & 1.08 & 0 & $1 \cdot 00$ & 1.85 & $12 \cdot 0$ \\
\hline LP944 & & & & & & $1 \cdot 62$ & $\mathbf{0}$ & 1.00 & 1.41 & $4 \cdot 0$ \\
\hline & & & & & & $\begin{array}{l}3.91 \\
3.02\end{array}$ & $\begin{array}{l}0.58 \\
0.36\end{array}$ & $\begin{array}{l}1.00 \\
1.00\end{array}$ & $\begin{array}{l}1.49 \\
1.05\end{array}$ & $\begin{array}{r}14 \cdot 1 \\
5.7\end{array}$ \\
\hline LP1894 & & & & & & 1.93 & 0.57 & $1 \cdot 00$ & $1 \cdot 24$ & $\begin{array}{l}5 \cdot 7 \\
8 \cdot 8\end{array}$ \\
\hline & & & & & & $3 \cdot 72$ & $0 \cdot 22$ & 1.00 & $1 \cdot 24$ & $2 \cdot 0$ \\
\hline LP2707 & & & 0 & $4 \cdot 10$ & 2.08 & $4 \cdot 39$ & 0.97 & 1.00 & 1.08 & $13 \cdot 5$ \\
\hline LP856a & & & $\begin{array}{l}0 \\
0\end{array}$ & $\begin{array}{l}6.09 \\
3.95\end{array}$ & $\begin{array}{l}1.96 \\
2.40\end{array}$ & $5 \cdot 39$ & 0.48 & 1.00 & 1.08 & $8 \cdot 1$ \\
\hline LFo.joa & & & 0 & $\begin{array}{l}5.95 \\
4.72\end{array}$ & $\begin{array}{l}2.40 \\
3.22\end{array}$ & $\begin{array}{l}3 \cdot 97 \\
4 \cdot 65\end{array}$ & $\begin{array}{l}0.88 \\
0.75\end{array}$ & $\begin{array}{l}1.00 \\
1.00\end{array}$ & $\begin{array}{l}1.53 \\
0.88\end{array}$ & $\begin{array}{r}15.5 \\
5.0\end{array}$ \\
\hline LP1107 & & & 0 & $3 \cdot 29$ & 1.95 & $3 \cdot 19$ & 0.49 & $1 \cdot 00$ & 0.59 & $9 \cdot 6$ \\
\hline & & & 0 & $4 \cdot 48$ & $3 \cdot 47$ & $5 \cdot 15$ & 0.41 & 1.00 & $1 \cdot 76$ & 4.9 \\
\hline LPI 123 & & & 0 & 3.81 & 1.27 & $3 \cdot 14$ & 0.53 & 1.00 & 0.96 & $10 \cdot 5$ \\
\hline & & & $\mathbf{0}$ & 3.83 & 2.93 & $3 \cdot 80$ & 0.57 & 1.00 & $0 \cdot 82$ & $4 \cdot 5$ \\
\hline LP2214 & & & 0 & 2.98 & 1.90 & 2.05 & 0.75 & 1.00 & $1 \cdot 00$ & $13 \cdot 5$ \\
\hline & & & $\mathbf{0}$ & $4 \cdot 83$ & $2 \cdot 16$ & $4 \cdot 99$ & 0.76 & 1.00 & $1 \cdot 71$ & $6 \cdot 2$ \\
\hline LP2706 & & & 0 & $5 \cdot 33$ & $2 \cdot 30$ & $4 \cdot 56$ & $1 \cdot 36$ & 1.00 & $1 \cdot 54$ & $14 \cdot 5$ \\
\hline LP898 & & & $\begin{array}{l}\mathbf{0} \\
\mathbf{0}\end{array}$ & $\begin{array}{l}3.87 \\
2.49\end{array}$ & $\begin{array}{l}2.17 \\
1.87\end{array}$ & $\begin{array}{l}3.64 \\
2.36\end{array}$ & $\begin{array}{l}0.60 \\
0.64\end{array}$ & 1.00 & $1 \cdot 07$ & $\begin{array}{r}7.4 \\
11.7\end{array}$ \\
\hline L10 0 & & & 0 & 2.90 & 2.32 & $3 \cdot 77$ & $\begin{array}{l}0.04 \\
0.53\end{array}$ & $\begin{array}{l}1.00 \\
1.00\end{array}$ & $\begin{array}{l}1 \cdot 15 \\
1.18\end{array}$ & $\begin{array}{r}11 \cdot 7 \\
4 \cdot 0\end{array}$ \\
\hline LP1174 & & & 0 & $4 \cdot 19$ & $2 \cdot 30$ & $4 \cdot 65$ & $1 \cdot 29$ & 1.00 & 1.57 & $14 \cdot 5$ \\
\hline & & & 0 & $4 \cdot 11$ & $1 \cdot 18$ & $3 \cdot 65$ & $1 \cdot 15$ & 1.00 & 0.84 & $7 \cdot 2$ \\
\hline LP1339 & & & 0 & $3 \cdot 96$ & $1 \cdot 11$ & $3 \cdot 47$ & $0 \cdot 38$ & 1.00 & $0 \cdot 81$ & $15 \cdot 6$ \\
\hline JP2155 & & & 0 & $\begin{array}{l}2.97 \\
6.35\end{array}$ & $\begin{array}{l}1.38 \\
2.45\end{array}$ & 2.96 & 0.85 & 1.00 & 0.73 & $8 \cdot 1$ \\
\hline LP2155 & & & 0 & $\begin{array}{l}6.35 \\
4.25\end{array}$ & $\begin{array}{l}2.45 \\
1.91\end{array}$ & $4 \cdot 16$ & $1 \cdot 18$ & 1.00 & $1 \cdot 28$ & $10 \cdot 0$ \\
\hline LP2671 & & & 0 & 3.41 & $\begin{array}{l}1.91 \\
1.78\end{array}$ & $\begin{array}{l}4 \cdot 50 \\
3.52\end{array}$ & $\begin{array}{l}0.94 \\
0.90\end{array}$ & $\begin{array}{l}1.00 \\
1.00\end{array}$ & $\begin{array}{l}0.99 \\
1 \cdot 31\end{array}$ & $\begin{array}{l}6 \cdot 4 \\
9 \cdot 2\end{array}$ \\
\hline & & & 0 & $4 \cdot 43$ & $2 \cdot 44$ & $4 \cdot 54$ & 0.29 & 1.00 & $1 \cdot 50$ & $6 \cdot \overline{2}$ \\
\hline LP903 & & & $1 \cdot 80$ & 1.78 & $2 \cdot 58$ & $1 \cdot 10$ & 0 & 1.00 & 0.75 & $9 \cdot 4$ \\
\hline & & & 1.83 & $2 \cdot 24$ & $4 \cdot 21$ & $1 \cdot 62$ & 0 & 1.00 & 0.88 & $3 \cdot 7$ \\
\hline LP1674 & & & 0.78 & 1.53 & $2 \cdot 18$ & 0.71 & 0 & 1.00 & 0.77 & $12 \cdot 7$ \\
\hline & & & $2 \cdot 33$ & $2 \cdot 71$ & $5 \cdot 65$ & $2 \cdot 15$ & 0 & $1 \cdot 00$ & 1.06 & $6 \cdot 2$ \\
\hline LP1170 & & & $2 \cdot 57$ & 1.81 & $3 \cdot 14$ & 0.89 & 0 & 1.00 & $1 \cdot 13$ & $11 \cdot 2$ \\
\hline LP609 & & & $2 \cdot 70$ & $2 \cdot 47$ & 6.04 & 0.92 & 0 & 1.00 & $1 \cdot 16$ & $6 \cdot 0$ \\
\hline LPOUY & & & $\begin{array}{l}0 \\
0\end{array}$ & $\begin{array}{r}9 \cdot 49 \\
\end{array}$ & 1.86 & $1 \cdot 14$ & 2.80 & $1 \cdot 00$ & $1 \cdot 26$ & $2 \cdot 1$ \\
\hline LP729 & & & 0 & $\begin{array}{l}10 \cdot 21 \\
13 \cdot 13\end{array}$ & $\begin{array}{l}1.10 \\
1.13\end{array}$ & $\begin{array}{l}1.40 \\
0.98\end{array}$ & 2.41 & $\begin{array}{l}1.00 \\
1.00\end{array}$ & $\begin{array}{l}0.59 \\
1.27\end{array}$ & $\begin{array}{l}1 \cdot 8 \\
4 \cdot 5\end{array}$ \\
\hline & & & 0 & 13.82 & 2.60 & $2 \cdot 21$ & $3 \cdot 9 \overline{3}$ & 1.00 & 0.94 & 1.4 \\
\hline LP1977 & & & 0 & $9 \cdot 61$ & $2 \cdot 01$ & $1 \cdot 33$ & $3 \cdot 35$ & $1 \cdot 00$ & 0.46 & $4 \cdot 1$ \\
\hline & & & 0 & $8 \cdot 18$ & $2 \cdot 08$ & $1 \cdot 44$ & 1.69 & $1 \cdot 00$ & $2 \cdot 15$ & $1 \cdot 8$ \\
\hline LP1255 & & & 0 & $10 \cdot 85$ & $1 \cdot 80$ & $1 \cdot 10$ & 3.64 & $1 \cdot 00$ & 0.92 & $3 \cdot 0$ \\
\hline & & & & $15 \cdot 05$ & $2 \cdot 16$ & 1.47 & $2 \cdot 35$ & 1.00 & 0.71 & $1 \cdot 7$ \\
\hline LP2212 & & & 1.04 & 0 & $2 \cdot 79$ & $2 \cdot 83$ & 0 & $1 \cdot 00$ & $0 \cdot 88$ & $14 \cdot 0$ \\
\hline & & & $1 \cdot 50$ & 0 & 4.46 & $2 \cdot 80$ & 0 & $1 \cdot 00$ & 0.88 & $5 \cdot 0$ \\
\hline LP2506 & & & 0.41 & 0 & $2 \cdot 31$ & 2.07 & 0 & 1.00 & $1 \cdot 36$ & $9 \cdot 1$ \\
\hline & & & 0.75 & $\mathbf{0}$ & $4 \cdot 10$ & $3 \cdot 37$ & 0 & 1.00 & 2.02 & $2 \cdot 5$ \\
\hline LP1301 & & & $1 \cdot 31$ & 0 & $3 \cdot 43$ & $3 \cdot 45$ & 0 & $1 \cdot 00$ & $1 \cdot 25$ & $18 \cdot 5$ \\
\hline & & & 0.79 & 0 & 3.88 & $3 \cdot 40$ & 0 & $1 \cdot 00$ & $0 \cdot 83$ & $9 \cdot 0$ \\
\hline LP1395 & & & $\begin{array}{l}0.93 \\
1.41\end{array}$ & $\begin{array}{l}0 \\
0\end{array}$ & $\begin{array}{l}3.02 \\
3.95\end{array}$ & $\begin{array}{l}2.66 \\
3.40\end{array}$ & $\begin{array}{l}0 \\
0\end{array}$ & $\begin{array}{l}1.00 \\
1.00\end{array}$ & $\begin{array}{l}0.76 \\
1.16\end{array}$ & $\begin{array}{r}16.0 \\
7.9\end{array}$ \\
\hline & & & & & & & & & & \\
\hline F470 & PW & $16 \cdot 9$ & 0 & 0.11 & $1 \cdot 35$ & $\begin{array}{l}1.44 \\
1.18\end{array}$ & 0 & $1 \cdot 00$ & $1 \cdot 31$ & $\cdots$ \\
\hline $\begin{array}{l}\text { F576 } \\
\text { F653 }\end{array}$ & $\begin{array}{l}\text { PW } \\
\text { PW }\end{array}$ & $\begin{array}{l}10 \cdot 1 \\
10.5\end{array}$ & $\begin{array}{l}0 \\
0\end{array}$ & $\begin{array}{l}0.25 \\
0.21\end{array}$ & $\begin{array}{l}1.00 \\
0.70\end{array}$ & $\begin{array}{l}1 \cdot 18 \\
1.67\end{array}$ & $\begin{array}{l}0 \\
0\end{array}$ & $\begin{array}{l}1.00 \\
1.00\end{array}$ & $\begin{array}{l}1.05 \\
1.40\end{array}$ & $\cdots$ \\
\hline & & & & & & & & & & $\cdots$ \\
\hline
\end{tabular}

*KDO = 3-deoxy-D-manno-octulosonic acid. 
Chemical analysis. The sugar composition of LPS from the three rough and 28 smooth strains are shown in table III. Glucose, galactose, L-glyceroD-mannoheptose and KDO were found as major components of the polysaccharide portion of the LPS from strains F470, F576 and F653; small amounts of mannose were also detected. The major core components were found in all S-LPS preparations. In addition, LPS from $E$. coli $\mathrm{O} 2$ and $\mathrm{O} 18$ strains contained rhamnose; O6 and O9 LPS contained mannose; and both rhamnose and mannose were found in LPS from 07 strains. However, in all preparations from $E$. coli $\mathrm{O} 6$ and $\mathrm{O} 9$ strains, but in none from $\mathrm{O} 2, \mathrm{O} 7$ and $\mathrm{O} 18$ strains, an additional peak with a retention time relative to glucose ( $R$ glu) of 2.09-2.12 was found (fig. 1). Previous studies (Adams, Quadling and Perry, 1967; Dmitriev et al., 1971) indicate that this peak might be the alditol acetate of D-glycero-D-mannoheptose. The alditol acetate derived from an authentic sample of D-glycero-D-mannoheptose gave a $\mathrm{R}$ glu value of $2 \cdot 10$. The authentic sugar was added to hydrolysates of phenol-extracted LPS from strain LP729 and alditol acetates were prepared; the heptose and the unidentified component appeared in chromatographs as a single peak. The sugar was therefore tentatively identified as D-glycero-D-mannoheptose; futher characterisation of this component is in progress.

The presence of D-glycero-D-mannoheptose raises the question of whether it is associated with the core or the $O$ side-chain. Phenol-extracted LPS was therefore subjected to mild hydrolysis with acetic acid and the resulting degraded polysaccharides were fractionated by gel filtration on Sephadex G50. Previous studies have shown that gel filtration of degraded polysaccharides from S LPS gives three peaks (Schmidt et al., 1969), peak I containing predominantly $\mathrm{O}$-side-chain material, peak II representing the core moiety and peak III consisting of mono-, di- and trisaccharides. The elution profile obtained with degraded polysaccharides from strain LP729 is shown in fig. 2. Peak I was excluded from the column with the void volume; subsequent peaks were small, indicating that in LPS from this strain the majority of core " stubs" are substituted with $\mathrm{O}$ side-chains. The neutral sugar composition of the various peaks is shown in table IV; D-glycero-D-mannoheptose was associated exclusively with the O-side-chain fractions (peak I).

Several minor peaks were evident in some chromatograms of S-LPS hydrolysates. A peak with a retention time slightly greater than that of hexa-O-acetyl glucitol was frequently found (peak X; fig. 1); this peak represents a conversion or degradation product of L-glycero-D-mannoheptose during acid hydrolysis (Schmidt et al., 1970). It is assumed that the small ribitol-penta-acetate peak that was found in a few of the chromatograms was due to slight contamination with ribonucleic acid.

The relative molar amounts of rhamnose (serogroups $\mathrm{O} 2, \mathrm{O} 7$ and $\mathrm{O} 18$ ) or mannose (serogroups O6 and O9) and L-glycero-D-mannoheptose were taken as a measure of the ratio of $\mathrm{O}$-side-chain sugar to core sugar. There was a tendency for this ratio to be greater in serum-resistant strains than in serum-sensitive strains (table III). The difference in ratios given by LPS extracted with phenal-water from paired serum-sensitive and serum-resistant 


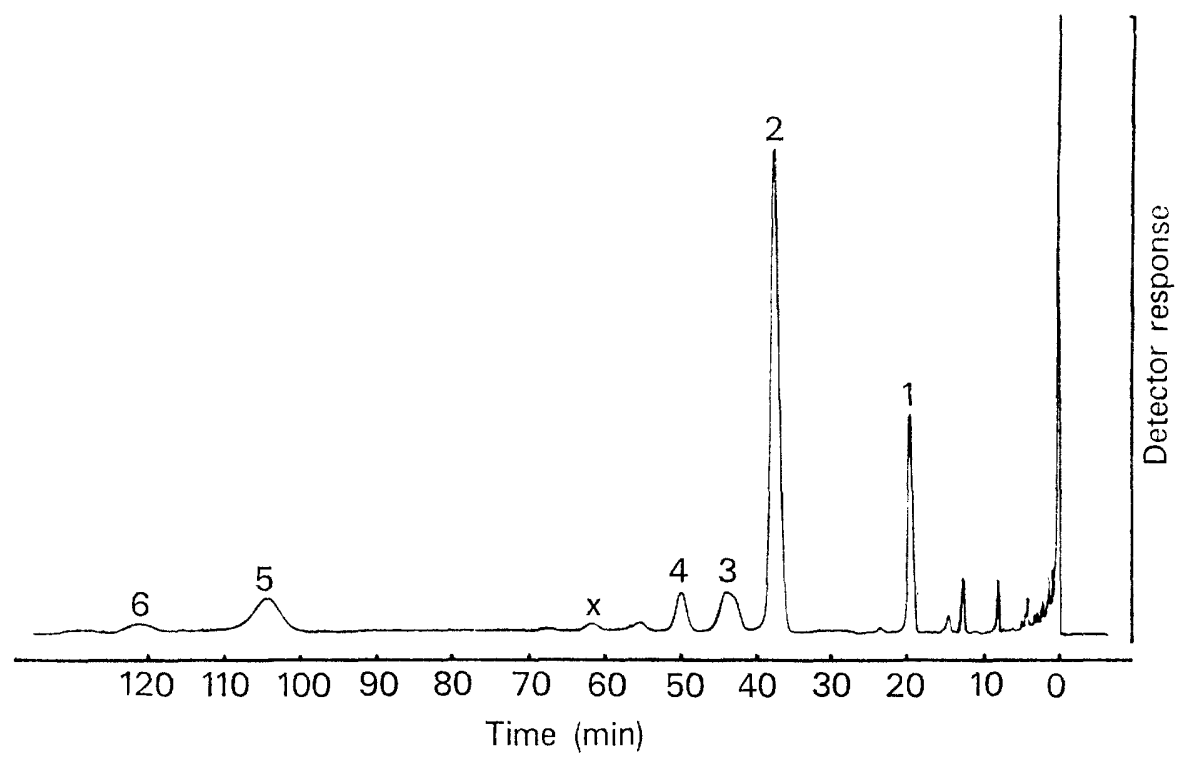

FIG. 1.-Gas-liquid chromatography on ECNSS-M columns of alditol acetates derived from hydrolysates of LPS from E. coli strain no. LP729. For chromatographic details, see Methods. Peaks represent derivatives of: 1 , xylose (internal standard); 2 , mannose; 3 , galactose; 4, glucose; 5, D-glycero-D-mannoheptose; 6, L-glycero-D-mannoheptose; $X$, degradation product of L-glycero-D-mannoheptose.

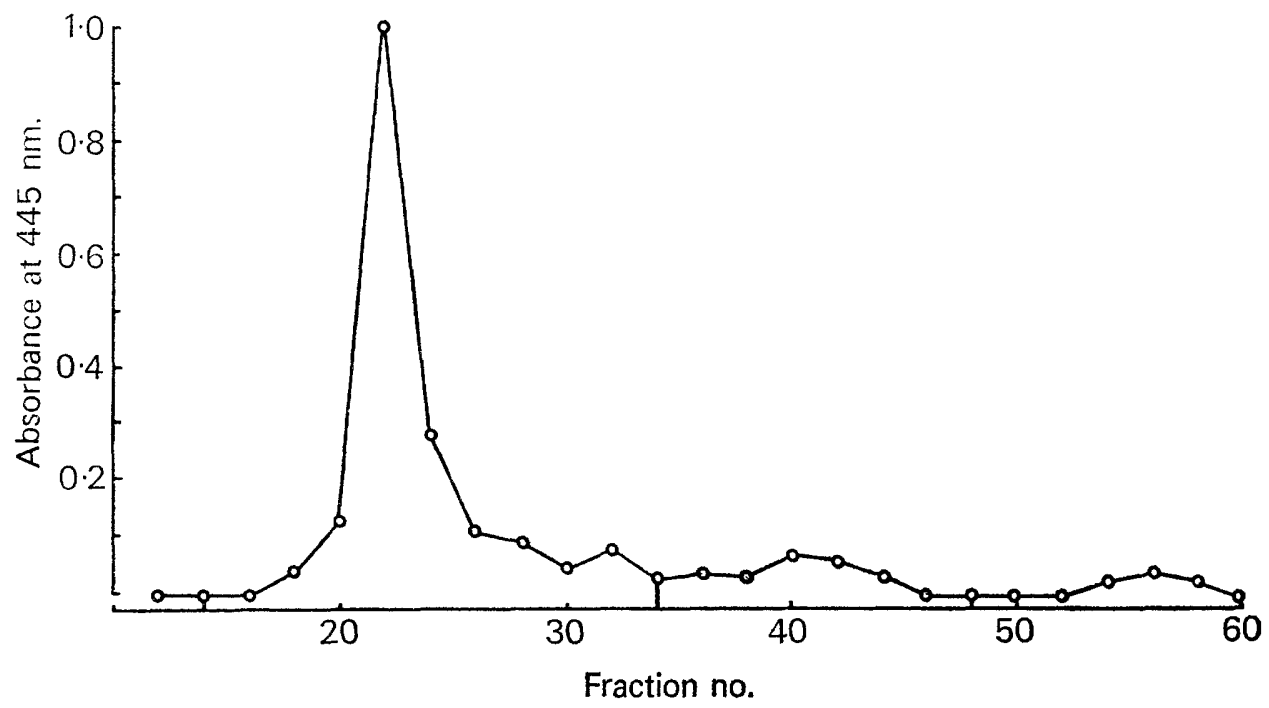

FIG. 2.-Fractionation of degraded polysaccharides from LPS of E. coli strain no. LP729 on Sephadex G50. Fractions were examined by the phenol- $\mathrm{H}_{2} \mathrm{SO}_{4}$ technique and the absorbance at $445 \mathrm{~nm}$ was measured. 
TABLE IV

Analysis of degraded polysaccharides from the phenol-extracted LPS $(50 \mathrm{mg})$ of E. coli strain no. LP729

\begin{tabular}{|c|c|c|c|c|c|c|c|}
\hline \multirow[b]{2}{*}{ Peak* } & \multirow[b]{2}{*}{ Fractions } & \multirow{2}{*}{$\begin{array}{l}\text { Weight } \\
\text { (mg) }\end{array}$} & \multicolumn{5}{|c|}{ Percentage amount of material in each peak } \\
\hline & & & Mannose & Galactose & Glucose & $\begin{array}{l}\text { D-glycero-D- } \\
\text { mannoheptose }\end{array}$ & $\begin{array}{l}\text { L-glycero-D- } \\
\text { mannoheptose }\end{array}$ \\
\hline $\begin{array}{l}\text { I } \\
\text { II } \\
\text { III }\end{array}$ & $\begin{array}{l}15-33 \\
34-47 \\
48-60\end{array}$ & $\begin{array}{r}21 \cdot 8 \\
2.6 \\
0.7\end{array}$ & $\begin{array}{r}61.9 \\
10.6 \\
9.6\end{array}$ & $\begin{array}{r}4 \cdot 0 \\
20 \cdot 6 \\
20 \cdot 4\end{array}$ & $\begin{array}{r}5 \cdot 3 \\
24 \cdot 8 \\
6 \cdot 4\end{array}$ & $\begin{array}{c}16 \cdot 8 \\
0 \\
0\end{array}$ & $\begin{array}{c}3 \cdot 3 \\
19 \cdot 0 \\
0\end{array}$ \\
\hline
\end{tabular}

* Material was fractionated on Sephadex G50 and fractions representing peaks I, II and III were pooled.

strains-as determined by the standard bactericidal test-was probably significant (mean difference $=0.67 ; t=2.301 ; \mathrm{P}<0.05$ ), but it was not when the modified serum responses were taken into account (mean difference $=0.31$; $t=0.880 ; 0.5>P>0.4)$. No significant mean differences were found with LPS extracted by the saline technique (standard test : mean difference $=1.63$; $t=1.801 ; 0.2>\mathrm{P}>0.1 ;$ modified test $:$ mean difference $=1.55 ; t=1.693$; $0 \cdot 2>\mathrm{P}>0 \cdot 1)$. The ratios obtained with the intermediate $\mathrm{O6}$ strains were similar to those found with other strains of this $\mathrm{O}$ serogroup.

There were no significant mean differences in total sugar content of LPS from serum-sensitive and serum-resistant strains whether they were extracted with phenol-water (standard test : mean difference $=2.61 \% ; t=0.650$; $0.6>\mathrm{P}>0.5 ;$ modified test : mean difference $=6.19 \% ; t=1.763 ; 0.2>\mathrm{P}>$ 0.1 ) or with saline (standard test : mean difference $=2.83 \% ; t=1.263$; $0.3>\mathrm{P}>0.2 ;$ modified test : mean difference $=3.67 \% ; t=1.763 ; 0.2>\mathrm{P}>$ $0 \cdot 1)$. Total sugar did, however, account for significantly more of the phenolwater than of the saline preparations (mean difference $=29.7 \% ; t=14 \cdot 145$; $\mathrm{P}<0.001)$.

\section{Studies on acidic polysaccharides}

Yield. There was considerable variation in the amount of acidic polysaccharide extracted from the smooth strains, ranging from $0.3 \%$ of the cell mass for the resistant strain LP2214 to 9\% for strain LP903 (table V). There were no significant differences in the mean yields of phenol-extracted acidic polysaccharide from serum-sensitive and serum-resistant strains as determined by either the standard test or the modified test (means 22.49 and $31.80 \mathrm{mg}$ per g; $t<1.315 ; \quad \mathbf{P}>0.05$ ). Similarly, the difference in the mean yields of salineextracted acidic polysaccharide was not significant when strains were classified as sensitive or resistant on the basis of the standard test (means 24.28 and $34.04 \mathrm{mg}$ per $\mathrm{g} ; t=1.036 ; 0.4>\mathrm{P}>0.3)$. However, when the modified serum responses were taken into account, a significant difference in the mean yields was found (means 16.14 and $42.04 \mathrm{mg}$ per $\mathrm{g} ; t=3.348 ; \mathrm{P}<0.005$ ). 
TABLE V

Analysis of acidic polysaccharides obtained by cetrimide precipitation from phenol-water $(P W)$ and warm saline (Sal) extracts of smooth E. coli strains

\begin{tabular}{|c|c|c|c|c|c|c|c|c|}
\hline \multirow{2}{*}{$\begin{array}{c}\text { Strain } \\
\text { no. }\end{array}$} & \multirow{2}{*}{ Serotype } & \multicolumn{2}{|c|}{$\begin{array}{l}\text { Grade of serum } \\
\text { sensitivity in }\end{array}$} & \multirow{2}{*}{$\begin{array}{c}\text { Extracting } \\
\text { agent }\end{array}$} & \multirow{2}{*}{$\begin{array}{l}\text { Yield: } \\
\text { mg per } \mathrm{g} \\
\text { of cell } \\
\text { mass }\end{array}$} & \multicolumn{2}{|c|}{ Presence of } & \multirow{2}{*}{$\begin{array}{l}\text { Amount ( } \mu \mathrm{g} \text { per ml) } \\
\text { required to double } \\
\text { the minimal haem- } \\
\text { agglutinating dose* }\end{array}$} \\
\hline & & $\begin{array}{c}\text { standard } \\
\text { test }\end{array}$ & $\underset{\text { test }}{\text { modified }}$ & & & $\begin{array}{c}\text { hexuronic } \\
\text { acid }\end{array}$ & $\underset{\text { acid }}{\text { neuraminic }}$ & \\
\hline LP1173 & $\mathrm{O} 2$ & 1 & 1 & PW & $\begin{array}{r}18 \cdot 8 \\
6 \cdot 0\end{array}$ & - & $\overline{-}$ & $\begin{array}{r}250 \\
>1000\end{array}$ \\
\hline LP2362 & $\mathrm{O} 2: \mathrm{K} ?: \mathrm{H} 6$ & 1 & 1 & $\mathrm{PW}$ & 12.8 & $\overline{-}$ & + & $\begin{array}{r}500 \\
>1000\end{array}$ \\
\hline LP1624 & $\mathrm{O} 2$ & 4 & 4 & PW & $19 \cdot 0$ & $\bar{t}$ & - & $\begin{array}{r}>1000 \\
0 \cdot 1\end{array}$ \\
\hline LP2017 & $\mathrm{O} 2: \mathrm{K} ?: \mathrm{H}-$ & 6 & 6 & $\begin{array}{l}\text { Sal } \\
\text { PW }\end{array}$ & $\begin{array}{l}20 \cdot 8 \\
30 \cdot 6\end{array}$ & \pm & $\bar{t}$ & $\begin{array}{l}0 \cdot 2 \\
4\end{array}$ \\
\hline & & & & Sal & $\begin{array}{l}36 \cdot 6 \\
25 \cdot 1\end{array}$ & $\bar{t}$ & \pm & $>1000$ \\
\hline LP944 & 06 & 1 & 1 & Sal & $\begin{array}{l}25 \cdot 1 \\
22 \cdot 6\end{array}$ & + & $\overline{-}$ & $32^{0.5}$ \\
\hline LP1894 & $\mathrm{O} 6: \mathrm{K} ?: \mathrm{H} 1$ & 1 & 1 & $\begin{array}{l}\mathrm{PW} \\
\mathrm{Sal}\end{array}$ & $\begin{array}{l}46 \cdot 0 \\
15.8\end{array}$ & $\underline{-}$ & $\overline{-}$ & $\begin{array}{l}>1000 \\
>1000\end{array}$ \\
\hline LP2707 & $\mathrm{O} 6: \mathrm{K} ?: \mathrm{H}-$ & 1 & 1 & PW & $\begin{array}{l}23.2 \\
18.8\end{array}$ & $\stackrel{t}{t}$ & $\overline{-}$ & $\begin{array}{r}16 \\
4\end{array}$ \\
\hline LP856a & O6 & 1 & 1 & $\mathrm{PW}$ & $\begin{array}{l}27 \cdot 1 \\
32 \cdot 0\end{array}$ & $=$ & $\overline{-}$ & 62 \\
\hline LP1107 & 06 & 6 & 6 & $\begin{array}{l}\text { PW } \\
\text { Sal }\end{array}$ & $\begin{array}{l}43 \cdot 6 \\
26 \cdot 2\end{array}$ & $\overline{-}$ & $\bar{z}$ & $\begin{array}{r}16 \\
32\end{array}$ \\
\hline LP1123 & 06 & 6 & 6 & $\begin{array}{l}\text { PW } \\
\text { Pal }\end{array}$ & $\begin{array}{l}28 \cdot 7 \\
38 \cdot 0\end{array}$ & $=$ & $\bar{z}$ & $\begin{array}{r}16 \\
-1000\end{array}$ \\
\hline LP2214 & $\mathrm{O} 6: \mathrm{K} ?: \mathrm{H} 31$ & 6 & 6 & $\begin{array}{l}\mathrm{Sal} \\
\mathrm{PW}\end{array}$ & $\begin{array}{r}38.0 \\
9.5\end{array}$ & $\bar{z}$ & $\bar{z}$ & 1000 \\
\hline LP2706 & $\mathrm{O} 6: \mathrm{K} ?: \mathrm{H} 31$ & 6 & 6 & PW & 31.8 & $\overline{-}$ & $\overline{-}$ & $>1000$ \\
\hline LP898 & O6 & 4 & 2 & PW & 34.7 & $\bar{z}$ & $\bar{z}$ & $\begin{array}{r}125 \\
32\end{array}$ \\
\hline LP1174 & O6 & 4 & 4 & PW & $43 \cdot 4$ & + & $\bar{z}$ & $\begin{array}{r}250 \\
2\end{array}$ \\
\hline LP1339 & O6 : K ? : H1 & 4 & 4 & PW & $\begin{array}{l}5.93 \\
36.1 \\
42.8\end{array}$ & $\stackrel{+}{+}$ & $=$ & 1 \\
\hline LP2155 & $\mathrm{O} 6: \mathrm{K} ?: \mathrm{H} 1$ & 4 & 5 & $\begin{array}{l}\text { Sal } \\
\text { PW }\end{array}$ & $\begin{array}{l}42.8 \\
48.9 \\
60 \cdot 3\end{array}$ & \pm & $\bar{z}$ & $0 \cdot 5$ \\
\hline LP2671 & $\mathrm{O} 6: \mathrm{K} 2 \mathrm{ac}: \mathrm{H} 1$ & 4 & 1 & PW & 45.4 & $=$ & - & 0.5 \\
\hline LP903 & 07 & 1 & 6 & PW & $\begin{array}{l}49 \cdot 7 \\
80.8\end{array}$ & - & + & $\begin{array}{r}8 \\
8\end{array}$ \\
\hline LP1674 & 07 & 1 & 6 & PW & $20 \cdot 9$ & - & + & 16 \\
\hline LP1170 & 07 & 5 & 1 & PW & $27 \cdot 6$ & + & \pm & 250 \\
\hline LP609 & 09 & 1 & 1 & PW & 11.6 & I & - & $>1000$ \\
\hline LP729 & 09 & 1 & 1 & PW & 18.0 & - & - & $>1000$ \\
\hline LP1977 & $\mathrm{O} 9: \mathrm{K} 26 \mathrm{a}: \mathrm{H} 10$ & 1 & 1 & PW & 11.8 & - & $\overline{-}$ & $>1000$ \\
\hline LP1255 & 09 & 6 & 6 & $\begin{array}{l}\mathrm{Sal} \\
\mathrm{PW}\end{array}$ & $\begin{array}{r}3 \cdot 3 \\
43 \cdot 0\end{array}$ & $\overline{+}$ & $\overline{-}$ & $\begin{array}{l}>1000 \\
>1000\end{array}$ \\
\hline LP2212 & O18ac : K ?: H5 & 1 & 1 & $\begin{array}{l}\text { Sal } \\
\text { PW }\end{array}$ & $\begin{array}{l}54 \cdot 1 \\
10 \cdot 6\end{array}$ & \pm & $\bar{z}$ & $\begin{array}{l}>1000 \\
>1000\end{array}$ \\
\hline & & & 1 & Sal & $15 \cdot 5$ & - & $\overline{+}$ & $>1000$ \\
\hline LP2506 & O18ac:K?:H- & 1 & 1 & $\stackrel{\mathrm{PW}}{\mathrm{Sal}}$ & $30 \cdot 2$ & $\overline{-}$ & $\stackrel{+}{+}$ & $\begin{array}{l}32 \\
32\end{array}$ \\
\hline LP1301 & $\mathrm{O} 18$ & 6 & 5 & PW & 37.4 & \pm & $\overline{-}$ & $0 \cdot 5$ \\
\hline LP1395 & 018 & 6 & 6 & $\begin{array}{l}\text { Pa } \\
\text { Sal }\end{array}$ & $\begin{array}{l}35.6 \\
71.8\end{array}$ & $\begin{array}{l}+ \\
+\end{array}$ & $\bar{z}$ & $\begin{array}{l}4 \\
1 \\
4\end{array}$ \\
\hline
\end{tabular}

* See Methods.

Similar values were obtained when mean differences were assessed. More material was extracted from serum-intermediate $E$. coli 06 strains than from serum-sensitive or serum-resistant O6 strains (table V).

Chemical analysis. Polysaccharides from 10 strains were found to contain hexuronic acid (table V). Large amounts of neuraminic acid were found in acidic polysaccharides from five strains. Neither hexuronic acid nor neuraminic acid could be detected in polymers from the remaining 13 strains. There was 
no obvious relationship between the serum sensitivity of a strain and the type of polymer it produced. Chromatography and spectrophotometry indicated that a few of the acidic polysaccharides were contaminated with $1-5 \%$ of ribonucleic acid. Small amounts of protein were found in all saline-extracted polymers.

Inhibition of red cell agglutination. Some serum-sensitive and serumresistant strains produced acidic polysaccharides with high HAI activity; both groups also contained strains that produced polymers with no detectable activity (table V). There was no significant mean difference between the activity of preparations from serum-sensitive strains and serum-resistant strains, whether they were extracted with phenol-water (standard test: $t=1.427$; $0.2>\mathrm{P}>0.1$; modified test: $t=2.008 ; 0.1>\mathrm{P}>0.05$ ) or with saline (standard test: $t=0.539 ; 0.7>\mathrm{P}>0.6 ;$ modified test: $t=0.850 ; 0.5>\mathrm{P}>0.4)$. The majority of hexuronic-acid-containing polymers were very effective inhibitors. The preparations from the serum-intermediate $E$. coli $\mathrm{O} 6$ strains were more inhibitory than those from either the serum-sensitive or serum-resistant O6 strains (table V). The phenol-water preparations appeared to be more effective inhibitors than the saline preparations $(t=2.721 ; \mathrm{P}<0.025)$.

\section{DisCUSSION}

It is evident that no one theory of serum resistance explains the responses to serum of all the $E$. coli strains examined in this study.

There was little difference in the amount of LPS which could be extracted from the bacteria by either the phenol-water or the saline techniques. No attempt was made to determine the proportion of LPS remaining in the bacterial mass after extraction.

In general, more O-side-chain material was associated with LPS from serumresistant than from serum-sensitive strains. In only one of four statistical analyses, however, were the differences significant. LPS from some resistant strains, such as no. LP2214, contained smaller amounts of O-side-chain sugars than sensitive strains of the same $O$ serotype (table III). The quantitative analysis presented in table III gives no indication of the degree of substitution of LPS core " stubs " by O side-chains, and it is possible that a higher proportion of stubs are substituted in LPS from serum-resistant than from serum-sensitive strains. This is supported by the observation that some serum-sensitive strains are resistant to $\mathrm{R}$-specific phages. Fractionation of degraded polysaccharides suggested, however, that in at least one serum-sensitive strain, no. LP729, the LPS contained few unsubstituted core stubs. This strain was also sensitive to phage F0; $\mathrm{N}$-acetylglucosamine is an essential part of the receptor for this phage (Lindberg and Holme, 1969) and is present in the $E$. coli R2 core as a short side chain attached to the distal glucose unit (Hämmerling et al., 1971). It appears, therefore, that even substantial amounts of $\mathrm{O}$-side-chain material may not always prevent some phages from interacting with core components. In addition, with all LPS preparations examined, anti-R antibodies were able to react with antigenic determinants in the core despite the presence of varying 
amounts of $\mathrm{O}$ side-chains. These results suggest that $\mathrm{O}$-specific side-chains may not be able to prevent macromolecules, such as activated complement components, from reaching sites deeper in the outer membrane of the cell wall. The increase in serum sensitivity that accompanies the loss by mutation of O side-chains (Dlabač, 1968) may, therefore, be related to the simulataneous decrease in protein content of the outer membrane (Ames, Spudich and Nikaido, 1974). A small number of serum-sensitive mutants derived from serum-resistant salmonellae by Nelson and Roantree (1967) retained the cultural characteristics of the smooth parent strains and showed unaltered LPS O-side-chain-sugar to core-sugar ratios.

There was wide variation in the amount of extractable acidic polysaccharide in serum-sensitive and serum-resistant strains, and the lowest yields were obtained from a serum-resistant strain, no. LP2214 (table V). Although only very small amounts of such substances were obtained from a number of strains, such as no. LP729, they functioned as $\mathrm{K}$ antigens in tests with anti-O and antiOK sera (P. W. Taylor, unpublished data). No statistically significant differences were found between the HAI activity of polymers from serum-sensitive and serum-resistant strains. There was also no obvious relationship between the amount of polymer that could be extracted and its inhibiting activity, the combined effects of which might be expected to determine the total activity of crude homogenates. Many of the more effective inhibitors contained hexuronic acid, suggesting that the inhibitory activity might be related to the charge carried by this polymer. Whether this is related to the ability of the polymer to repel cationic macromolecules or to a higher affinity for the red-cell surface is not known. The lower haemagglutination-inhibiting activity of the salineextracted polymers may be due to their containing small amounts of protein which might reduce the total negative charge or the red-cell-binding capacity of the polymers.

Some serum-resistant strains contained neither large amounts of acidic polysaccharides nor LPS O-side-chain material and it is likely that resistance in these strains is due to other factors. Jann et al. (1970) found an O-inagglutinable $E$. coli strain with no polysaccharide representing a distinct $\mathrm{K}$ antigen and suggested that the cell surface might carry a protein "inagglutinability factor."

The results of the present study indicate, therefore, that serum resistance in $E$. coli may have a multifactorial basis. The observation that changes in cultural conditions may modify the response to serum raises the possibility that these factors could be identified and characterised in individual strains by the effect of various growth environments on the cell surface and serum sensitivity.

In contrast to the salmonellae, a number of distinct LPS core types have been recognised among the $E$. coli serotypes. Passive-haemagglutination and haemagglutination-inhibition tests indicated that most of the strains in the present study probably possess the $\mathrm{R} 1$ core structure; two strains have the R2 core and none have the R3 core.

Recently, two additional $E$. coli core types have been recognised (Schmidt, 
1973; Schmidt, Jann and Jann, 1974). The K12 core is serologically distinct from the R1, R2 and R3 cores (Schmidt, 1973). Although LPS from rough strains possessing the complete R4 core cross react to some extent in anti-R1 sera, extensive cross reactivity in R antisera is not apparent in tests with LPS from smooth strains (Schmidt et al., 1969). The finding of a sugar resembling D-glycero-D-mannoheptose in hydrolysates of many of the LPS from smooth strains was unexpected, because this sugar is not generally recognised as being a constituent of $E$. coli antigens (Lüderitz et al., 1971). The sugar was found in all preparations from serogroups $\mathrm{O} 6$ and $\mathrm{O} 9$ but was absent from $\mathrm{O} 2, \mathrm{O} 7$, O18 and R LPS (table III); it was also associated exclusively with highmolecular-weight O-side-chain fractions after Sephadex G50 chromatography of degraded polysaccharides from strain LP729 (table IV). Therefore, although direct evidence is lacking, it seems likely that D-glycero-D-mannoheptose is linked to the O-side-chain moiety of the LPS in some strains of E. coli. Dglycero-D-mannoheptose has been found in LPS extracted from Proteus mirabilis (Kotelko, Lüderitz and Westphal, 1965) and was considered by Bagdian et al. (1966) to be a component of the $\mathrm{O}$ side-chain in strains of this species. Adams et al. (1967) found D-glycero-D-mannoheptose in LPS from seven species of gram-negative bacteria, including $E$. coli, and considered this heptose to be a common component of LPS. However, Lehmann et al. (1973) examined LPS from some of the strains tested by Adams et al. (1967) and did not find D-glycero-D-mannoheptose in any of them.

Thirteen of 28 strains produced polymers that formed compexes with cetrimide, and thus carried a net negative charge, but contained no detectable hexuronic acid or neuraminic acid. Relatively large amounts of these polymers, frequently with high haemagglutination-inhibiting activity, were obtained from a number of strains. Glycerol phosphate is known to confer acidic properties on exopolysaccharies from some strains of E. coli (Jann et al., 1970); further studies will be necessary to determine whether any of the strains in the present study produce polymers of this nature.

\section{SUMMARY}

Factors that may determine the variable resistance of urinary strains of Escherichia coli to the bactericidal activity of normal human serum have been analysed. No statistically significant difference was found in the amount of lipopolysaccharide (LPS) that could be extracted from serum-sensitive and serum-resistant strains by either the phenol-water or warm-saline techniques. The ratio of LPS O-side-chain sugars to core sugars was not found to be significantly greater in serum-resistant than in serum-sensitive strains. A sugar resembling D-glycero-D-mannoheptose was found in LPS from some of the strains; in one case the sugar was shown to be associated with the O-sidechain moiety. Lipopolysaccharides from all but two of the strains contained the $E$. coli $\mathrm{R} 1$ core structure.

No consistent difference was observed between serum-sensitive and serumresistant strains in either the amount of acidic polysaccharide extracted or its 
red-cell agglutination-inhibiting activity; nor was a clear relationship found between sensitivity to serum and sensitivity to R-specific bacteriophages.

It is concluded that no one mechanism of serum resistance explains the response to serum of the $E$. coli strains examined in this study.

\section{REFERENCES}

Adams, G. A., Quadling, C. ANd Perry, M. B. 1967. D-glycero-D-manno-heptose as a component of lipopolysaccharides from Gram-negative bacteria. Can. J. Microbiol., $13,1605$.

Ames, G. F.-L., SpUdich, E. N. AND Nikaido, H. 1974. Protein composition of the outer membrane of Salmonella typhimurium: effect of lipopolysaccharide mutations. J. Bact., 117, 406.

BAgDian, G., DröGe, W., KotelKo, K., LÜDERITZ, O. AND WestPhal, O. 1966. Vorkommen zweier Heptosen in Lipopolysacchariden enterobakterieller Zellwände: L-Glycero- und D-Glycero-D-manno-heptose. Biochem. Z., 344, 197.

BarRy, G. T., ABbott, V. AND Tsai, T. 1962. Relationship of colominic acid (poly Nacetylneuraminic acid) to bacteria which contain neuraminic acid. J. gen. Microbiol., 29, 335.

Chedid, L., Parant, M., Parant, F. and Boyer, F. 1968. A proposed mechanism for natural immunity to Enterobacterial pathogens. J. Immun., 100, 292.

Dische, Z. 1947. A new specific color reaction of hexuronic acids. J. biol. Chem., 167, 189.

DLABAČ, V. 1968. The sensitivity of smooth and rough mutants of Salmonella typhimurium to bactericidal and bacteriolytic action of serum, lysozyme and to phagocytosis. Folia Microbiol., Praha, 13, 439.

Dmitriev, B. A., Hinton, N. A., Lowe, R. W. ANd Jones, J. K. N. 1971. Studies on lipopolysaccharides of Proteus. Can.J. Microbiol., 17, 1385.

Dubois, M., Gilles, K. A., Hamilton, J. K., Rebers, P. A. and Smith, F. 1956. Colorimetric method for determination of sugars and related substances. Anal. Chem., 28, 350.

Ellwood, D. C. 1970. The distribution of 2-keto-3-deoxy-octonic acid in bacterial walls. J. gen. Microbiol., 60, 373.

FeINGOLD, D. S. 1969. The serum bactericidal reaction. IV. Phenotypic conversion of Escherichia coli from serum-resistance to serum-sensitivity by diphenylamine. J. infect. Dis., 120, 437.

Galanos, C., Reitschel, E. T. L., Lüderitz, O. AND WestPhal, O. 1971. Interaction of lipopolysaccharides and lipid A with complement. Eur. J. Biochem., 19, 143.

Ghalambor, M. A., Levine, E. M. AND Heath, E. C. 1966. The biosynthesis of cell wall lipopolysaccharide in Escherichia coli. III. The isolation and characterization of 3deoxyoctulosonic acid. J. biol. Chem., 241, 3207.

GlynN, A. A. AND HowARD, C. J. 1970. The sensitivity to complement of strains of Escherichia coli related to their $\mathrm{K}$ antigens. Immunology, 18, 331.

HÄmmerling, G., LÜDeritz, O., WestPhal, O. AND Mäkelä, P. H. 1971. Structural investigations on the core polysaccharide of Escherichia coli O100. Eur.J. Biochem., 22, 331.

Hickman, J. AND Ashwell, G. 1966. Isolation of a bacterial lipopolysaccharide from Xanthomonas campestris containing 3-acetamido-3,6-dideoxy-D-galactose and Drhamnose. J. biol. Chem., 241, 1424.

Holme, T., Lindberg, A. A., GARegG, P. J. AND ONN, T. 1968. Chemical composition of cell wall polysaccharide of rough mutants of Salmonella typhimurium. J.gen. Microbiol., $52,45$.

INOUE, K. 1972. Immune bacteriolytic and bactericidal reactions. In Research in immunochemistry and immunology, edited by J. B. G. Kwapinski, Baltimore, vol. 1, p. 177.

J. MED. MICROBIOL.-VOL. 9 (1976) 
JANN, B., JANN, K., SchmidT, G., ØRSKov, I. AND ØRSKov, F. 1970. Immunochemical studies of polysaccharide surface antigens of Escherichia coli $\mathrm{O} 100: \mathrm{K}$ ?(B) : H2. Eur. J. Biochem., 15, 29.

KotelKo, K., LÜDERITZ, O. AND WeStPhal, O. 1965. Vergleichende Untersuchungen an Antigenen von Proteus mirabilis und einer stabilen L-Form. Biochem. Z., 343, 227.

Lehmann, V., Hämmerling, G., Nurminen, M., Minner, I., RuschmanN, E., LüDeritz, O., Kuo, T. T. AND Stocker, B. A. D. 1973. A new class of heptose-defective mutant of Salmonella typhimurium. Eur. J. Biochem., 32, 268.

LindBerg, A. A. AND Holme, T. 1969. Influence of O-side chains on the attachment of the Felix O-1 bacteriophage to Salmonella bacteria. J. Bact., 99, 513.

Lowry, O. H., Rosebrough, N. J., FARR, A. L. AND Randall, R. J. 1951. Protein measurement with the Folin phenol reagent. J. biol. Chem., 193, 265.

LÜDeritz, O., Westrhal, O., Staub, A. M. and Nikaido, H. 1971. Isolation and chemical and immunological characterization of bacterial lipopolysaccharides. In Microbial toxins, edited by G. Weinbaum, S. Kadis and S. J. Ajl, London, vol. 4, p. 145.

Mergenhagen, S. E., Gewurz, H., Bladen, H. A., Nowotny, A., Kasai, N. ANd Lüderitz, O. 1968. Interactions of the complement system with endotoxins from a Salmonella minnesota mutant deficient in O-polysaccharide and heptose. J. Immun., 100, 227.

MÜller-SeITZ, E., JANN, B. AND JANN, K. 1968. Degradation studies on the lipopolysaccharide from $E$. coli $\mathrm{O} 71: \mathrm{K}$ ? : H12. Separation and investigation of $\mathrm{O}$-specific and core polysaccharides. FEBS Letters, 1, 311.

MusCHEL, L. H. 1960. Bactericidal activity of normal serum against bacterial cultures. II. Activity against Escherichia coli strains. Proc. Soc. exp. Biol. Med., 103, 632.

MusChel, L. H. AND LARSEN, L. J. 1970. The sensitivity of smooth and rough Gramnegative bacteria to the immune bactericidal reaction. Proc. Soc. exp. Biol. Med., 133, 345.

Nelson, B. W. AND RoANTREe, R. J. 1967. Analyses of lipopolysaccharides extracted from penicillin-resistant serum-sensitive Salmonella mutants. J. gen. Microbiol., 48, 179.

RAFF, R. A. AND WheAt, R. W. 1968. Carbohydrate composition of the phenol-soluble lipopolysaccharides of Citrobacter fruendii. J. Bact., 95, 2035.

RAPIN, A. M. C. AND KalCKAR, H. M. 1971. The relation of bacteriophage attachment to lipopolysaccharide structure. In Microbial toxins, edited by G. Weinbaum, S. Kadis and S. J. Ajl, London, vol. 4, p. 267.

Reynolds, B. L. AND PruUl, H. 1971. Sensitization of complement-resistant smooth Gram-negative bacterial strains. Infect. Immun., 3, 365 .

Rowley, D. AND WARDLAW, A. C. 1958. Lysis of Gram-negative bacteria by serum. J. gen. Microbiol., 18, 529.

SAwardeker, J. S., Sloneker, J. H. AND Jeanes, A. 1965. Quantitative determination of monosaccharides as their alditol acetates by gas liquid chromatography. Anal. Chem., 37, 1602.

Schlecht, S. ANd WeStPhal, O. 1967. Über die Herstellung von Antiseren gegen die somatischen $(\mathrm{O}-)$ Antigene von Salmonellen. I. Mitteilung: Untersuchungen über Agglutinintiter. Zentbl Bakt. ParasitKde, I Abt. Orig., 204, 335.

SCHMIDT, G. 1973. Genetical studies on the lipopolysaccharide structure of Escherichia coli K12. J. gen. Microbiol., 77, 151.

Schmidt, G., Fromme, I., AND MaYer, H. 1970. Immunochemical studies on core lipopolysaccharides of Enterobacteriaceae of different genera. Eur. J. Biochem., 14, 357.

SCHMIDT, G., JANN, B., AND JANN, K. 1969. Immunochemistry of R lipopolysaccharides of Escherichia coli: different core regions in the lipopolysaccharides of $\mathrm{O}$ group 8. Eur.J. Biochem., 10, 501.

SchmidT, G., JANN, B. AND JANN, K. 1974. Genetic and immunochemical studies on Escherichia coli $\mathrm{O} 14: \mathrm{K} 7: \mathrm{H}-$. Eur. J. Biochem., 42, 303.

Strominger, J. L., Park, J. T. And Thompson, R. E. 1959. Composition of the cell wall of Staphylococcus aureus: its relation to the mechanism of action of penicillin. J. biol. Chem., 234, 3263. 
TAYLOR, P. W. 1974. The sensitivity of some smooth strains of Escherichia coli to the bactericidal action of normal human serum. J. clin. Path., 27, 626.

TAYlor, P. W., RoBerts, A. P. AND Gower, P. E. 1972. Evaluation of a technique for the estimation of serum bactericidal activity against Gram-negative organisms. Med. Lab. Technol., 29, 272.

WARDLAW, A. C. 1963 . The complement-dependent bacteriolytic activity of normal human serum. II. Cell wall composition of sensitive and resistant strains. Can.J. Microbiol., 9, 41.

WestPhal, O. AND JANN, K. 1965. Bacterial lipopolysaccharides: extraction with phenolwater and further applications of the procedure. In Methods in carbohydrate chemistry, edited by R. L. Whistler, London, vol. 5, p. 83.

WILCOXON, F. 1945. Individual comparisons by ranking methods. Biometrics Bull., 1, 80. 